The American Journal of Political Science Law and Criminology

(ISSN - 2693-0803)

VOLUME 04 ISSUE 01 Pages: 41-46

SJIF IMPACT FACTOR (2020: 5. 453) (2021: 5 • 952)

OCLC - 1176274523 METADATA IF - 7.659

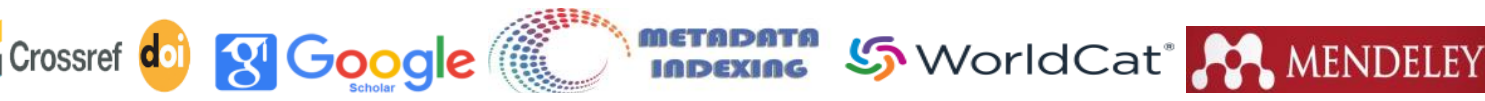

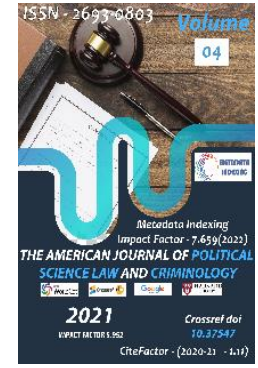

Journal Website: https://theamericanjou rnals.com/index.php/ta jpslc

Copyright: Original content from this work may be used under the terms of the creative commons attributes 4.0 licence. (2)earch Article

\section{MODERN TRENDS IN REGULATION OF ENVIRONMENTAL AND LEGAL RELATIONS: DIGITALIZATION AND ARTIFICIAL INTELLIGENCE}

\author{
Submission Date: January 09, 2022, Accepted Date: January 20, 2022, \\ Published Date: January 30, 2022 \\ Crossref doi: https://doi.org/10.37547/tajpslc/Volume04lssue01-07
}

Durbek Makhkamov

Ph.D. assistant professor, Tashkent state university of law, Uzbekistan

\title{
ABSTRACT
}

The current state of the procedure for the use of natural resources is analyzed. It has been established that the regulatory legal acts regulating these relations do not fully reflect the capabilities of modern approaches and technologies. Foreign models in this area, the influence of theoretical concepts on legislation are evaluated. In addition, the use of artificial intelligence in the use of natural resources was predicted. Among the global trends in the development of environmental law, the processes of globalization and the stages of penetration of information and communication technologies stand out. Issues of further improvement of the mechanisms for the use of some natural resources that are part of public services and increasing the interest of state bodies in this area were discussed. Proposals for the development of new normative legal acts or for the introduction of amendments and additions to them were put forward and classified according to their nature.

\section{KEYWORDS}

E-government, green economy, automation, natural resource, environmental safety, electronic digital signature.

\section{INTRODUCTION}

The pandemic has also affected scientific thinking as a phenomenon that has led to the emergence of new relationships around the world. In particular, concepts such as the digital economy, electronics, IT 
The American Journal of Political Science Law and Criminology

(ISSN - 2693-0803)

VOLUME 04 ISSUE 01 Pages: 41-46

SJIF IMPACT FACTOR (2020: 5. 453) (2021: 5. 952)

OCLC - 1176274523 METADATA IF - 7.659

Crossref do

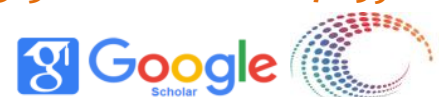

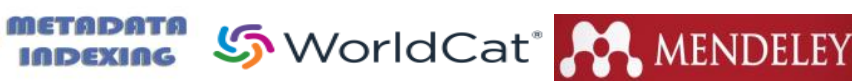

Publisher: The USA Journals

technologies affect every industry. These changes are an objective need and the need to regulate certain relations.

The unprecedented development of information and communication technologies is rapidly entering the realm of public administration. In public life, such specific systems as "electronic government", "electronic government", "electronic court" and "smart regulation", "smart law" and "virtual legal space" are becoming more widespread in public life. administration of the Republic of Uzbekistan. RNI occupies. The influence of the Internet as a means of global communication and communication on the life of society, the state and the individual is so important that this process requires not only in-depth scientific research in many areas, but also appropriate organizational measures on the part of states and the international community also requires attention. The rapid development of social relations, which in some cases is difficult to predict, will undoubtedly pose very difficult tasks for modern law. In this regard, the question of what are the trends in the development of modern law is natural. According to scientific sources, today the process of globalization and the unprecedented development of the media are among the world trends in the development of law, which is a strong impetus for the development of relations between states and peoples [1] .

For example, various electronic resources and social networks have become the most effective means of influencing government bodies and their officials. In this regard, the rapid penetration of digital technologies into all spheres of society, their widespread use in the process of public control creates conditions for the formation and development of "electronic public control" [2].
In the modern world, no area of jurisprudence, in particular environmental relations, is not excluded from the influence of modern technologies, computerization of activities. This, in turn, will need to be taken into account in the daily activities of users of natural resources and environmentalists.

It should be noted that the President of the Republic of Uzbekistan in 2020 according to Decree in order to introduce the state information system in the field of biosafety, officials, as well as raise public awareness, develop an innovative telecommunications management structure, develop and implement data protection tools, methods and mechanisms in the field of biological safety. It also provides for the development and implementation of modern methods, means and technologies for protecting the population from the effects of hazardous biological factors and protecting the environment.

In this regard, the proper use of natural resources is gradually becoming electronic.

One of the key issues is the introduction of an information system for the provision of the following state services in the field of environmental protection in electronic form:

- issuance of permits for ozone-depleting substances and products containing them;

- state environmental certification;

- issuance of permits for the use of objects of flora and fauna;

- issuance of permits for special water use or special water use.

In addition, important reforms in the field of cadastre are associated with digitalization. In particular, in 20202022 , it is planned to create access to open data on state cadastre objects in the National Geographic 
The American Journal of Political Science Law and Criminology

(ISSN - 2693-0803)

VOLUME 04 ISSUE 01 Pages: 41-46

SJIF IMPACT FACTOR (2020: 5. 453) (2021: 5. 952)

OCLC - 1176274523 METADATA IF - 7.659

Information System.In particular, the placement of available information on each layer of state cadastres on an open geoportal:

- information about cadastral objects of land, buildings and structures;

- cadastre of highways;

- $\quad$ state railway cadastre;

- state cadastre of supply pipelines;

- $\quad$ state cadastre of power lines;

- $\quad$ state forest cadastre;

- water cadastre;

- state cadastres of flora and fauna;

- state cadastre of deposits, minerals and products of technogenic origin;

- state cadastre of specially protected natural areas;

- state cadastre of burial and disposal of waste;

- $\quad$ state cadastre of hydraulic structures;

- state Cadastre of Cultural Heritage Objects;

- state cadastre of communication objects;

- expand the possibility of creating and using thematic layers in the authorized bodies for each of the state cadastres of a man-made and especially dangerous state [3].

\section{METHODS}

The following methods were used in the study: structural-logical, comparative-legal, statistical, descriptive, system-structural, as well as dialectical method of scientific knowledge, collection and analysis of scientific and practical material

\section{RESULT}

It should be noted that the trend of digitalization is reflected not only in organizational and legal issues of practical importance, but also in scientific and theoretical views.
For example, according to G. Uzakova, "Solving the urgent problems of cities should be solved taking into account modern methods of influencing public relations based on the level of urban pollution. In this regard, it is advisable to introduce an annual "environmental rating" of cities by the State Committee for Ecology and Environmental Protection with a wide involvement of the public." [4].

In this regard, O. Narzullaev said: "The introduction of efficient technologies is of particular importance in the history of civilization. At the international level, population growth is necessary to meet the demand for natural resources and agricultural products, ensure the rational use of natural resources, achieve progress through the formation of a regulatory framework for the introduction of scientific achievements and innovative technologies in sustainable development" [5].

Today, reforms related to the digitalization of environmental legal relations are largely limited to automation. Based on the experience of foreign countries, it is important to organize the next stage based on the concept of industry regulation through artificial intelligence. In this sense, there is a big difference between digitalization and artificial intelligence. For example, it is advisable that the relevant state bodies unite into a single system used in the process of environmental control within their competence, create a system for identifying cases of use and damage to natural resources, control and manage the entire process using artificial intelligence. Therefore, it is time to introduce artificial intelligence in the field of environmental protection, rational use of natural resources and environmental safety of the population, study its theoretical and legal aspects, develop a fundamental concept, conduct research. 
The American Journal of Political Science Law and Criminology

(ISSN - 2693-0803)

VOLUME 04 ISSUE 01 Pages: 41-46

SJIF IMPACT FACTOR (2020: 5. 453) (2021: 5. 952)

OCLC - 1176274523 METADATA IF - 7.659

How artificial intelligence, which is part of our daily life, affects the legal field? It should be noted that artificial intelligence is a field of research in which traditional intellectual models and methods for solving problems are developed and, most importantly, do not rely on formalization and automation, i.e. systems are studied, a removable system is being developed. It uses certain programming technologies and computing tools of a special architecture. The concept of intellect (lat. Intellectus) refers to the mind, the ability to think logically, rationally understand and think. Interestingly, such a system will be able to independently configure, identify and apply new risk profiles [6].

In order to implement these and many other topical issues, on February 17, 2021, the President of the Republic of Uzbekistan adopted a resolution "On measures to create conditions for the accelerated introduction of artificial intelligence technologies". The document provides for the creation of a local ecosystem in the field of artificial intelligence and the necessary conditions for developers, legal regulation of the industry, etc. [7].

It should be noted that the spread of artificial intelligence technologies in all spheres of society poses new challenges for researchers and developers. Given these challenges, Uzbekistan needs to create all conditions for scientists and engineers involved in the development of artificial intelligence. The country needs a new and entrepreneurial workforce with a deep understanding of technology, able to develop new ideas to expand the frontiers of knowledge in this area [8].

In fact, each of these natural phenomena has its own characteristics. For example, improving water management systems when using water, introducing Smart Water and similar digital technologies when taking into account the use and consumption of water; further expansion and stimulation of the introduction of water-saving irrigation technologies in the cultivation of crops, attracting foreign investment and grants in this area; introduction of public-private partnerships and outsourcing in the water sector, automation of the management of large water bodies based on digital technologies, the widespread introduction of modern technologies that save electricity and other resources.

Given that this topic is an emerging area of environmental law and has not been sufficiently studied, it is possible to express initial views and approaches.

1. The introduction of modern and advanced information and communication technologies in the field of environmental protection and nature management in the digital economy will make it possible to constantly increase the transparency of the activities of the competent state bodies and organizations.

2. Digital reform should begin, first of all, with the introduction of the most modern methods and tools in the process of state environmental control in order to minimize the human factor in order to achieve quality and high efficiency.

3. It is important to use the capabilities of artificial intelligence in identifying and predicting risks in environmental insurance. World experience shows that each country in the field of environmental insurance is associated with the creation of its own national environmental insurance system [9] and the use of artificial intelligence in the early detection of natural disasters and natural disasters, pays great attention to data protection. .

4. When conducting research in the field of environmental law, it is advisable to formulate 
The American Journal of Political Science Law and Criminology

(ISSN - 2693-0803)

VOLUME 04 ISSUE 01 Pages: 41-46

SJIF IMPACT FACTOR (2020: 5. 453) (2021: 5 • 952)

OCLC - 1176274523 METADATA IF - 7.659

Crossref

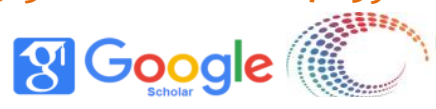

metapata

5) WorldCat"

Publisher: The USA Journals

scientific and theoretical ideas that predict the tendency for the penetration of artificial intelligence into the sphere of public relations. For example, the draft Environmental Code, which has been discussed and planned for adoption in Uzbekistan over the past 3-4 years, should be finalized by assessing the impact of artificial intelligence on certain environmental legal relations. Because scientific and theoretical ideas need to be formed earlier, faster and on a larger scale than the legislative process. This is evidenced by the fact that this situation is considered a key priority in the scientific and theoretical concepts of leading foreign countries [10].

5. As far as we know, scientists have put forward a system of views and concepts on the relationship between society and nature [11]. Based on the above considerations and the environmental policy of states, we can say that a new category of environmental legal theories has emerged. It is proposed to conditionally express this concept as "The concept of digitalization of environmental management". The structure of this concept differs from other representations in its complexity and in the fact that its full development takes a long time.

\section{CONCLUSION}

Thus, artificial intelligence plays an important role in the legal regulation of the use of natural resources by citizens, the creation of favorable conditions for citizens by public authorities, the prevention of corruption, and the full provision of human rights to the use of natural resources. The concept we propose will help legally protect and guarantee activities in this area.
Bringing the reforms carried out not only in Uzbekistan, but also in Central Asia to the level of modern requirements, will open a wide range of legal and practical ways for people, owners of natural resources, business, and agriculture.

In general, it is natural that the form and content of legal acts regulating the use of natural resources will change under the influence of modern approaches and technologies. Our foreign experience and scientific base prove that this change is positive and will ultimately serve to protect nature.

\section{REFERENCES}

1. Akhmedshaeva. The main trends in the development of law in modern times // Bulletin of Legal Sciences. - 2018. Issue 2.

2. Sh. Yakubov. Electronic Public Control: Essence, Significance, Necessity and Prospects // Bulletin of Legal Sciences. - 2020. Issue 3

3. National Database of Legislation, 06.10.2020, No. 20.06.6079/1349; 02/04/2021, 06/21/6198/0269

4. G. Uzakova. Legal procedure for the use and protection of natural resources in settlements. legitimate fan. doctor ... dis. 2021

5. O. Narzullaev. Improving the legal regulation of the protection and use of biological resources in Uzbekistan. Monograph. - Tashkent: TSUL, 2020.- 232 p.

6. U.Ibragimov. Issues of using artificial intelligence in the process of customs control // Uzbek customs bulletin.-2020. Number 2.

7. National database of legislation, 18.02.2021, No. 07/21/4996/0127; National Database of Legislation, 29.07.2021, No. 21.07.5199/0721

8. https://yuz.uz/ru/news/iskusstvenny-intellekt--sovremennoe-trebovanie-v-razvitii-obestva-igosudarstva? 
The American Journal of Political Science Law and Criminology

(ISSN - 2693-0803)

VOLUME 04 ISSUE 01 Pages: 41-46

SJIF IMPACT FACTOR (2020: 5. 453) (2021: 5. 952)

OCLC -1176274523 METADATA IF -7.659

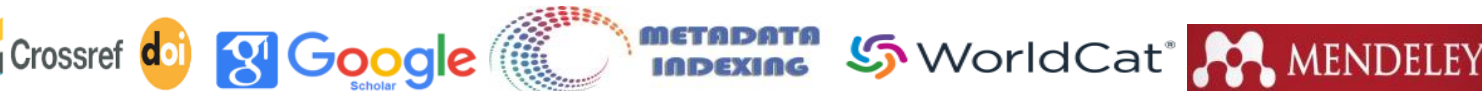

Publisher: The USA Journals

9. Tooth, R., and G. Barker. 2007. The NonInsured: Who, Why and Trends, Report prepared for the Insurance Council of Australia. Accessed November 17, 2017. http://www.insurancecouncil.com.au/; Turkish Catastrophe Insurance Pool (TCIP). 2017. Accessed November 17, 2017. http://www.tcip.gov.tr/; Linnerooth-Bayer, J., A. Vari, and R. Mechler. 2005. "Designing a Disaster Insurance Pool: Participatory and Expert Approaches in Hungary and Turkey," In Catastrophic Risks and Insurance. OECD: Paris

10. www.europarl.europa.eu/RegData/etudes/ST UD/2021/662906/IPOL_STU(2021)662906_EN.p df

11. Environmental law. Team of authors. Textbook. -2001. 